Portland State University

PDXScholar

\title{
Building Reuse as a Sustainable Practice in Architecture
}

Mykalene J. Piva

Portland State University

Follow this and additional works at: https://pdxscholar.library.pdx.edu/honorstheses Let us know how access to this document benefits you.

\section{Recommended Citation}

Piva, Mykalene J., "Building Reuse as a Sustainable Practice in Architecture" (2019). University Honors Theses. Paper 668.

https://doi.org/10.15760/honors.681

This Thesis is brought to you for free and open access. It has been accepted for inclusion in University Honors Theses by an authorized administrator of PDXScholar. Please contact us if we can make this document more accessible: pdxscholar@pdx.edu. 


\title{
Building Reuse as a Sustainable Practice in Architecture
}

\author{
Mykalene Piva \\ Honors Thesis Portland State University \\ Margarette Leite
}

March 2019 
Building Reuse as a Sustainable Practice in Architecture 1

Introduction 3

The Value of Existing Buildings $\quad 4$

Evaluation Methods $\quad 5$

Historic Designations in Portland $\quad 6$

Multi-Objective Decision-Making (MODM)- Huey-Jiun Wang and Zhi-Teng Zeng 7

Multi-Attribute Value Theory (MVAT) - Valentina Feretti, Marta Bottero and Giulio Mondini $\quad 8$

$\begin{array}{ll}\text { Life Cycle Assessment (LCA) } & 9\end{array}$

$\begin{array}{ll}\text { Embodied Energy } & 10\end{array}$

Case Study: The COR Building 11

COR Building: History and Relevance $\quad 11$

Assumptions

$\begin{array}{ll}\text { Evaluation Methods } & 15\end{array}$

MODM

MVAT 16

$\begin{array}{ll}\text { Life Cycle Assessment } & 17\end{array}$

$\begin{array}{ll}\text { Building Systems } & 17\end{array}$

Roof 17

Flooring 18

Siding 19

Ceiling Tiles $\quad 20$

Elevator $\quad 21$

Insulation $\quad 21$

Embodied Energy 23

New Construction $\quad 24$

Cost 24

Embodied Energy 25

Comparison $\quad 26$

$\begin{array}{ll}\text { Conclusion } & 27\end{array}$

$\begin{array}{ll}\text { Bibliography } & 30\end{array}$ 


\section{Introduction}

Throughout the world a shift of focus from production to sustainability has begun to take hold. While the idea of sustainability and reuse became popular in the 1970's, it has largely been ignored, but as time goes on, the ability for us to ignore it is diminishing. The field of architecture must recognize and embrace sustainable practices if we have any hope for a healthy and sustainable future. The writer of the book, Building Reuse, Kathryn Merlino recognized the truth of this idea in stating; "Buildings are the greatest contribution to climate change globally."1 Merlino's book details the undeniable truth about the impact of building construction on the world, and the ways in which architects can be more responsible and resourceful with their designs. Buildings have a large impact on the environment beginning long before they are built and lasting long after they are torn down. When considering energy use in the United States, $75 \%$ of all electricity produced in the nation goes to building operation, and $47 \%$ of all energy. ${ }^{2}$ The CO2 emissions from building construction and operation is up to $40 \%$ of all emissions in the nation. These numbers alone begin to show the extent to which buildings influence the environment, and these don't yet take into consideration the material use and waste that occurs in construction and demolition. In a study done by the Brookings Institute, they estimated that from 2003-2020 nearly 300 billion sq. ft. of the 427 billion sq. $\mathrm{ft}$. of built environment will be demolished in the U.S ${ }^{3}$. More than a third of the nations-built environment, and when one considers that $43 \%$ of all the nations construction and demolition (C\&D) waste goes to the landfill, the influence of demolition becomes unimaginable. Taking into consideration the influence that architecture has on the environment, this thesis aims to present building reuse as a

\footnotetext{
${ }^{1}$ Merlino, Kathryn Rogers. Building Reuse: Sustainability, Preservation, and the Value of Design. Seattle: University of Washington Press, 2018.

${ }^{2}$ Ibid

${ }^{3} \mathrm{Ibid}$
} 
viable option for a great percentage of buildings, and not just those that are historically or culturally significant. Using Merino's text as a backbone to this study, this paper will take into consideration several methods for evaluating the value of existing buildings and the decisions that must be made in order to determine if a building is worthy of renovation or of demolition. Finally, this paper will examine a building in the Portland area that I previously studied in a design course at PSU and considered for renovation.

\section{The Value of Existing Buildings}

As America ages, so do its many buildings. This has led to the tearing down of many existing buildings. At the same time, there has been a growth in laws and governmental bodies protecting historic buildings. Existing buildings hold value in that they "embody the cultural, social and historical narratives of our diverse society." ${ }^{4}$ Because of this, many historically and culturally relevant buildings are given protections and are preserved. However, there are many buildings that hold very little to no historic or cultural significance that still hold a wealth of value in their building materials and in their embodied energy.

As Portland grows, so does the density of its buildings. This often means that existing buildings are torn down in order for new buildings to replace them. While this is common practice, it is not always the most sustainable or economical way to think about the built environment. A common misconception about existing buildings is that they are not sustainable due to their aged or non-existant technologies, ranging from HVAC to single pane windows. However, these advances in technology and mechanical systems have allowed for designers of the built environment to design first, and consider comfort later, meaning that sustainability and passive design are put aside. The lack of mechanical systems in the early 1900's meant that

\footnotetext{
${ }^{4}$ Merlino, Kathryn Rogers.
} 
designers had to take into consideration methods that would allow for the best possible ventilation and lighting throughout the day, making them more sustainable than many modern buildings, as they used passive design.

A common phrase in the architecture world is "the greenest building is one that's already built" and this has to do with the material value and embodied energy inherent in an existing building. As Merlino puts it, "buildings hold value as environmental artifacts." ${ }^{5}$ Because the building has already sourced its materials and has already gone through its construction emissions and energy usages it is already one step ahead of new buildings in terms of sustainability. New construction requires the demolition of the pre-existing building, resulting in an average of $155 \mathrm{lbs}$ of $\mathrm{C} \& \mathrm{D}$ waste per square foot of building that is torn down. ${ }^{6}$ The cost to demolish an existing building has impacts beyond the pure economics. They extend from $\mathrm{CO} 2$ emissions, material waste, and embodied energy, meaning that a new building already has preexisting environmental debt before its construction has even begun. It was found that it would take anywhere from twenty to eighty years for a building to offset its construction emissions. ${ }^{7}$

\section{Evaluation Methods}

In Portland, the most common reason for a building to be preserved or renovated is because of its historic value. This is due in part to the growth of the city. As more people move in, existing buildings, and sometimes neighborhoods, are torn down to be replaced by higher density building complexes. However, those buildings that have been deemed historically significant are given certain protections that often keep them from being torn down. Portland has two bodies that protect historic buildings, The National Register of Historic Buildings and

\footnotetext{
${ }^{5}$ Merlino, Kathryn Rogers.

${ }^{6}$ Ibid

${ }^{7}$ Ibid
} 
Portland Historic Places. Each body has its own method for determining value of buildings and therefore which buildings will be given their protection. On a larger scale, there are methods that have been designed to determine the value of existing buildings based on their cultural significance as well. This paper will evaluate, in parallel, various way in which existing buildings are evaluated today. However, given that existing buildings also hold value in terms of their material and environmental impact, other methods not related to historic and cultural value, must also be considered. Within her book, Merlino names a few methods by which the architecture industry has chosen to evaluate buildings. Among these the Life Cycle Assessment method and the methodology of determining the embodied energy of a building. These will be addressed in detail and inform the way in which this thesis will examine an existing building in Portland.

\section{Historic Designations in Portland}

Around the world there are different considerations for the treatment of historic buildings. In Portland, there are two main bodies that protect historic buildings. These are the National Register of Historic Buildings, and Portland Historic Places. The National Register of Historic Buildings considers building significance in relation to its historical context. A building must first be nominated for the list with a statement of intent, which includes the history of the building, justification of the nomination, physical descriptions, and the amount of historical integrity it has to its original form. ${ }^{8}$ Because buildings have to be nominated and have to have connections to historically or culturally significant events, many buildings are left off the list,

\footnotetext{
8 "Historic Resource Protections." Historic Resources and Preservation RSS. May 04, 2017. Accessed October 30 , 2018. https://www.portlandoregon.gov/bps/article/133692.
} 
and vulnerable to demolition without regard to their structural and material value. In Portland there is a ranking of protections afforded to historic buildings which determines the length of notice that must be given before a building can be demolished, and within that ranking, a further determination of whether the building may be demolished or must be deconstructed. ${ }^{9}$ All buildings constructed before 1920 must be deconstructed due to the presence of asbestos and lead paint. Aside from those buildings, the decision to demolish buildings on the national register is left up to the City of Portland in a City Council vote. ${ }^{10}$ This method, however leaves many buildings that are found to be important to the public, in the hands of value judgements of city council members.

\section{Multi-Objective Decision-Making (MODM)- Huey-Jiun Wang and Zhi-Teng Zeng}

After extensive research, the authors of the article "A multi-objective decision-making process for reuse selection of historic buildings," Huey-Jiun Wang and Zhi-Teng Zeng determined five main concerns when evaluating historic buildings, and which could be extended to all existing buildings: 1) the state of the building as it is now; 2) type of construction; 3 ) organization and original purpose; 4) state of the materials and 5) if the potential use justifies the cost of renovation. While considering these aspects, they then determined five values that make a building worthy of reuse: 1) historic value; 2) cultural and artistic value; 3) technological value; 4) scenic and contextual value, and 5) social value. In order to best evaluate the buildings in question, the authors created a panel of experts including architects, architectural historians, developers, owners, experts and contractors. These panel members were kept anonymous so as to

\footnotetext{
9 "Historic Resource Protections." Historic Resources and Preservation RSS. May 04, 2017. Accessed October 30 , 2018. https://www.portlandoregon.gov/bps/article/133692.

${ }^{10}$ Ibid
} 
not allow one to outweigh the others, and they all were asked to weigh in on the different criteria. These criteria were then weighted against each other, allowing the study to show that criteria that score lower in general may have a large impact on some of the more important criteria, thus preventing them from being ignored or forgotten.

This method is one that can be easily applied to many other buildings and modified to fit the needs and considerations of the locations and cities where the buildings stand.

\section{Multi-Attribute Value Theory (MVAT) - Valentina Feretti, Marta Bottero and Giulio}

\section{Mondini}

Written by Valentina Ferretti, Marta Bottero, and Giulio Mondini the article "Decision making and cultural heritage: An application of the Multi-Attribute Value Theory for the reuse of historic buildings" considers one method of analyzing and assigning value to buildings in order to determine if they should be renovated. The study evaluated 7 buildings on site to determine which would be best suited for renovation as a tourist center. The first step in their analysis was to determine the main goal, or purpose which was the "sustainability of the building to be reused for touristic purposes." $" 11$ They then decided on attributes within any building that would determine its value for reuse. These attributes included, "quality of context, economic activities, flexibility of the building, accessibility, and conservation level." Each of these attributes and the 7 buildings were presented to a panel of experts, including a historian, cultural heritage expert, planning expert, and an economic evaluation expert. ${ }^{12}$ These experts then assigned each of the 7

\footnotetext{
${ }^{11}$ Ferretti, Valentina, Marta Bottero, and Giulio Mondini. "Decision Making and Cultural Heritage: An Application of the Multi-Attribute Value Theory for the Reuse of Historical Buildings." Journal of Cultural Heritage 15, no. 6 (November/December 2014): 644-55. Accessed October 25, 2018. doi:10.1016/j.culher.2013.12.007.

12 Ibid
} 
buildings a value between 0 and 1 , according to each attribute. ${ }^{13}$ Each attribute was then given its own value, ranking them from most valuable or important to least valuable or important. The values assigned to each of the attributes was then weighted against the ranking of each attribute in order to find the building that scored best. This gave a preliminary decision as to which building would be best suited for reuse. Finally, the buildings and their attributes were subjected to sensitivity testing. When doing sensitivity testing, the weighting of each attribute was raised, in turn, to $40 \%$ while the rest were at $15 \%$. The sensitivity testing resulted in 3 buildings that were determined to be the best options for reuse. Among them was the building determined by the panel of experts to be best suited for reuse.

\section{Life Cycle Assessment (LCA)}

Life Cycle Assessment (LCA) is an assessment of the energy usages of a building from its conception to construction, to operating costs, to demolition. Using LCAs can help save on construction and operation costs, as well as lead to greater sustainability and "green" classifications. This considers both cost in dollars, as well as the cost to the environment, especially in the form of $\mathrm{CO}_{2}$ emissions. In a study considering the "Life Cycle Energy and Environmental Performance of a New University Building" it was found that the highest use of energy is in the HVAC and electrical systems. ${ }^{14}$ Within this article they also call out material embodied energies and material life span, to consider when those materials would need to be replaced during the lifetime of the building. In the article, "Life Cycle Assessment and Historic Buildings," Fredrick Berg and Mie Fuglseth found that a new building with new technology

\footnotetext{
${ }^{13}$ Ibid

14 Scheuer, Chris, et al. "Life Cycle Energy and Environmental Performance of a New University Building: Modeling Challenges and Design Implications." Energy and Buildings, vol. 35, no. 10, 2003, pp. 1049-1064., doi:10.1016/s0378-7788(03)00066-5.
} 
focused on sustainability will still take around 50 years for the energy savings to outweigh the emissions of the actual construction process. ${ }^{15}$ In another study cited by Kathryn Merlino, it was found that the time for energy savings to outweigh emission cost could end up being closer to 80 years. ${ }^{16}$ With the current push for progress within the architecture world, many buildings won't stay standing long enough for the cost of emissions during construction to be outweighed by the energy saving systems within the building.

\section{Embodied Energy}

The concept of embodied energy is one that is taken into account in the Life Cycle Assessment method, but it is also one that is often done independent of any other study foci. Embodied energy is the unrecoverable energy that has been used and is present within a building. Merlino calls out two types of embodied energy, the initial and the recurring. Initial embodied energy is the energy that was used in sourcing, transporting and putting together materials. This is the energy that is used before and during the construction of the building. ${ }^{17}$ Initial energy is then broken down into direct and indirect energy, this is the difference between the direct use of energy in transporting and assembling the materials, and indirect in processing and manufacturing them. ${ }^{18}$ Recurring embodied energy is the energy used in the upkeep of the building; maintenance, repairs, refurbishments and replacements. Methods for calculating embodied energy were created in 1967 in a paper by the University of Illinois Energy Use for Building Construction. These methods are still used by many people who study embodied energy

\footnotetext{
${ }^{15}$ Berg, Fredrik, and Mie Fuglseth. "Life Cycle Assessment and Historic Buildings: Energy-efficiency Refurbishment versus New Construction in Norway." Journal of Architectural Conservation 24, no. 2 (July 18, 2018): 152-67. Accessed October 28, 2018. doi:10.1080/13556207.2018.1493664. 
today, however the materials are limited to those that were available in 1967. Another paper written by the Advisory Council on Historic Preservation, Assessing the Energy Conservation Benefits of Historic Preservation; Methods and Examples provides methods that are more current (1979), and often used. The second article provides three methods for determining embodied energy which take into account the knowledge one has of the building they're studying and of the time they have to perform the study. The three methods are a concept model, survey model and an inventory model. In order to determine the embodied energy of the focal building of this thesis the concept model method will be employed.

\section{Case Study: The COR Building}

The focal building of this study was first introduced to me in a design studio last year, where we were prompted to design an office building for City of Roses Disposal and Recycling (COR). I will use the methods above, MODM, MVAT, embodied energy, and a cost analysis to determine the environmental and economic impact of renovating the building. As I am not an engineer, nor will I have contractors out to the site, the renovation estimates will be based on assumptions that I have made, or that are clearly needed. These assumptions and decisions will be clearly explained later in this paper.

\section{COR Building: History and Relevance}

Built in 1959, the office building that is the focus of this study was designed for office workers of a distribution facility. In 2001 the site was purchased by Oregon Recycling Systems (ORS). ORS then brought in machinery such as conveyor belts, drop chutes and metal storage bins that would be used to sort materials in the warehouse. There is no evidence that the office building was altered. In 2015 ORS went out of business leaving the building uninhabited and essentially abandoned until its purchase by current owner City of Roses Disposal and Recycling 
(COR) in 2017. "COR is a licensed Material Recovery Facility (MRF) that accepts dry waste and construction \& demolition (C\&D) debris." ${ }^{19}$ COR's values include hiring employees from diverse backgrounds, providing livable wages and leading Portland in $90 \%$ waste recovery rates. $^{20}$

Current State of the COR Building

\begin{tabular}{|c|c|c|c|c|}
\hline Building System & \begin{tabular}{|l|} 
Specific \\
Characteristics of \\
Structure \\
\end{tabular} & $\begin{array}{l}\text { Material } \\
\text { Lifespan }\end{array}$ & $\begin{array}{l}\text { Material } \\
\text { Lifespan } \\
\text { Remaining }\end{array}$ & $\begin{array}{l}\text { Updates } \\
\text { needed }\end{array}$ \\
\hline Structure & $\begin{array}{l}\text { Wooden Structural } \\
\text { system with steel } \\
\text { columns running } 12 \text { ' } \\
\text { apart }\end{array}$ & $\begin{array}{l}\text { Wood: } 100+ \\
\text { Steel: } 100+\end{array}$ & $40+$ & None \\
\hline Floors & $\begin{array}{l}\text { Plywood floors } \\
\text { running on } 2 \times 12 \\
\text { girders with poured in } \\
\text { place concrete in the } \\
\text { basement }\end{array}$ & $\begin{array}{l}\text { Plywood: } \\
100 \\
\text { Girders: } \\
100+ \\
\text { Concrete: } \\
100+\end{array}$ & $40+$ & None \\
\hline Exterior Walls & $\begin{array}{l}\text { Plywood exteriors } \\
\text { with wood paneling } \\
\text { along the East West } \\
\text { and South Facades. } \\
\text { Concrete masonry on } \\
\text { the first, second, and } \\
\text { third floors of the } \\
\text { North façade. Poured } \\
\text { in place concrete } \\
\text { along the walls of the } \\
\text { basement, with } \\
\text { windows left in above } \\
\text { ground locations. }\end{array}$ & $\begin{array}{l}\text { Plywood: } \\
100+ \\
\text { CMU: } 100+\end{array}$ & $\begin{array}{l}40+ \\
\text { however this } \\
\text { is limited } \\
\text { due to water } \\
\text { damage on } \\
\text { wood siding }\end{array}$ & $\begin{array}{l}\text { Siding needs to } \\
\text { be replaced on } \\
\text { East, West, and } \\
\text { South facades }\end{array}$ \\
\hline Interior Walls & $\begin{array}{l}\text { Interior walls are } \\
\text { simple } 2 x 4 \\
\text { construction with } \\
\text { sheet rocking }\end{array}$ & Wood: $100+$ & Wood: 40+ & $\begin{array}{l}\text { Walls will be } \\
\text { moved and } \\
\text { modified for } \\
\text { better office } \\
\text { flow and }\end{array}$ \\
\hline
\end{tabular}

\footnotetext{
19 "About." City of Roses Disposal. Accessed February 20, 2019. https://cityofrosesdisposal.com/. 20 Ibid
} 


\begin{tabular}{|c|c|c|c|c|}
\hline & & & & $\begin{array}{l}\text { overall work } \\
\text { environment }\end{array}$ \\
\hline Windows & $\begin{array}{l}\text { Aluminum frame } \\
\text { windows, with swing } \\
\text { out panes }\end{array}$ & $15-20$ years & Unknown & $\begin{array}{l}\text { All seem to be } \\
\text { in good } \\
\text { condition }\end{array}$ \\
\hline Roof & $\begin{array}{l}\text { Flat roof with a 1' } \\
\text { parapet }\end{array}$ & Asphalt: 40 & $\begin{array}{l}\text { Already in } \\
\text { place for } 60\end{array}$ & $\begin{array}{l}\text { Likely needs } \\
\text { replacement or } \\
\text { repairs }\end{array}$ \\
\hline $\begin{array}{l}\text { Building } \\
\text { Orientation }\end{array}$ & $\begin{array}{l}\text { Length is along the } \\
\text { East West orientation, } \\
\text { while width is along } \\
\text { the North South. The } \\
\text { North facing the } \\
\text { Recycling facility, } \\
\text { with the CMU } \\
\text { blocking some of the } \\
\text { sound from work }\end{array}$ & N/A & N/A & N/A \\
\hline Flooring & $\begin{array}{l}\text { Basement is poured in } \\
\text { place concrete, while } \\
\text { the three floors above } \\
\text { have carpeting }\end{array}$ & $\begin{array}{l}\text { Carpet: 8-10 } \\
\text { years }\end{array}$ & Unknown & $\begin{array}{l}\text { Resurfacing } \\
\text { will be needed } \\
\text { on all floors }\end{array}$ \\
\hline Ceilings & $\begin{array}{l}\text { Acoustical Tile } \\
\text { Ceiling }\end{array}$ & $\begin{array}{l}40+(25+ \\
\text { may contain } \\
\text { asbestos })\end{array}$ & $\begin{array}{l}\text { Already } 60 \\
\text { years old }\end{array}$ & $\begin{array}{l}\text { Need full } \\
\text { replacement }\end{array}$ \\
\hline Lighting & Fluorescent lighting & $\begin{array}{l}8,000 \text { to } \\
10,000+ \\
\text { hours }\end{array}$ & Unknown & $\begin{array}{l}\text { Replaced as } \\
\text { needed }\end{array}$ \\
\hline Lighting Controls & Manual & $30+$ & $\begin{array}{l}\text { Already in } \\
\text { place for } \\
60+\end{array}$ & $\begin{array}{l}\text { All still in good } \\
\text { condition }\end{array}$ \\
\hline
\end{tabular}

\section{Assumptions}

First, I am assuming that the current use of the building will stay the same. The current building is an office, and the owner will want to continue to use it as such. Within that, the floorplans may change some, as the current building has many walls, that may not need to be there for the current owner's usage. However, changes in the walls will not require a large 
amount of work, and can be taken down by the owner, therefore it was not considered within this study.

Secondly, the timber beams, girders, and wall framing that make up the main structure of the building along with the steel columns were found to be in good condition, and therefore the renovations that need to be done are all non-structural and function driven. Within the observations section, portions of the building were found to need fixing or renovation, these include; exterior siding/paneling, wall orientation, roof repairs, resurfacing floors, and ceiling panel replacements.

The last thing to consider for cost of renovation would be code considerations and permitting costs. After consulting with a local professional who is proficient with Portland Building Codes, the following information was found. ${ }^{21}$ Using Portland Maps, an online graphic information system (GIS) which includes information about site lines, zoning, assessor information, permitting and other similar information, the site was found to be zoned for General Industrial (IG2), noted as a warehouse. ${ }^{22}$ However, for this project we are looking at the office specifically, which is noted as Business Group B within the occupancy type and allowances. ${ }^{23}$ Business Group B allows a gross occupancy of $150 .^{24}$ This means that for every 150 sq. ft. of floor, one person is allowed, meaning that in the 11,232 sq. $\mathrm{ft}$. of space, the max occupancy is 75 people. This also tells us that each story in the building should have a minimum of two exits, and

\footnotetext{
21 "Code Analysis." E-mail to Jeshua De Jongh. February 18, 2019.

22 "PortlandMaps." PortlandMaps. Accessed February 20, 2019. https://www.portlandmaps.com/.

${ }^{23}$ International Code Council. "CHAPTER 3O CCUPANCY CLASSIFICATION AND USE ." CHAPTER 11 [RE] ENERGY EFFICIENCY | 2012 International Residential Code | ICC PublicACCESS. Accessed February 25, 2019. https://codes.iccsafe.org/content/IBC2018/chapter-3-occupancy-classification-and-use.

24 Icc. "CHAPTER 10 MEANS OF EGRESS ." CHAPTER 11 [RE] ENERGY EFFICIENCY | 2012 International Residential Code | ICC PublicACCESS. August 2017. Accessed February 25, 2019. https://codes.iccsafe.org/content/IBC2018/chapter-10-means-of-egress.
} 
that these exits should be at most $75^{\prime}$ from any place in the building. ${ }^{25}$ Within this chapter the plumbing requirements are also noted. For a business with 75 occupants, two bathrooms for both males and females are required, each one must also hold 3 toilets/urinals. Permits for plumbing and electric have already been acquired. Knowing that the toilets that already exist meet code requirements, and that permits for updates have already been acquired, this paper will not include those in the cost estimate. Within this study, and knowing from previous visits, an assumption was be made that these code restrictions have all been met by the building as it currently stands, and therefore the floorplan won't need modification.

\section{Evaluation Methods}

\section{MODM}

The Multi-Objective Decision Making method has 5 main concerns; the state of the building, construction, organization or original purpose, state of materials, and if the cost to modify the building is justified by the use. In order to determine these values, these concerns are weighted against 5 values: historic value; cultural value and artistic value; technological value; scenic and contextual value; and social context.

For this thesis, the values for each concern and attribute was assigned by the author according to the relevance to the known site, from $0-1$.

\begin{tabular}{|l|l|}
\hline Concern/Attribute & Value \\
\hline State of Building & .75 \\
\hline Construction & .75 \\
\hline Organization/purpose & 1 \\
\hline
\end{tabular}

25 ibid 


\begin{tabular}{|l|l|}
\hline State of Materials & .25 \\
\hline Cost vs Use & .75 \\
\hline Concern Average & .7 \\
\hline Historic & 0 \\
\hline Cultural and Artistic & 0 \\
\hline Technological & 0 \\
\hline Scenic/Contextual & 0 \\
\hline Social & 0 \\
\hline Attribute Average & 0 \\
\hline Overall Average & .35 \\
(Concern+Attribute) & \\
\hline
\end{tabular}

The value of the building itself is .7 when not considering the attributes that they were weighed against for this study. This means that without considering the context of the building, the structure itself still holds value. However, if as is often done when determining value of existing buildings, we only consider the attributes we find to be most important, the building only holds no value. For the sake of this thesis, the results of applying the MODM shows that existing buildings can hold value, even if they aren't historically or culturally significant.

MVAT

Within the Multi-Value Attribute Theory the authors looked at quality of context, economic activities, flexibility, accessibility, conservation level, and cultural significance. The values for this study were also determined on a scale from 0-1 by the author of this thesis.

\begin{tabular}{|l|l|}
\hline Attribute & Value \\
\hline Context & 0 \\
\hline
\end{tabular}




\begin{tabular}{|l|l|}
\hline Economy & .5 \\
\hline Flexibility & .75 \\
\hline Accessibility & .75 \\
\hline Conservation & 0 \\
\hline Cultural Significance & 0 \\
\hline Overall & .33 \\
\hline
\end{tabular}

For this study, the value of the structure itself isn't heavily weighted, therefore the value of the overall building is much lower than in the MODM method.

\section{Life Cycle Assessment}

Life Cycle Assessments take into consideration many aspects of a building's environmental and economic costs. For this thesis the cost to repair/renovate the building and the embodied energy costs will be considered. However, there are many other aspects to a Life Cycle Assessment that will not be taken into consideration.

\section{Building Systems}

\section{Roof}

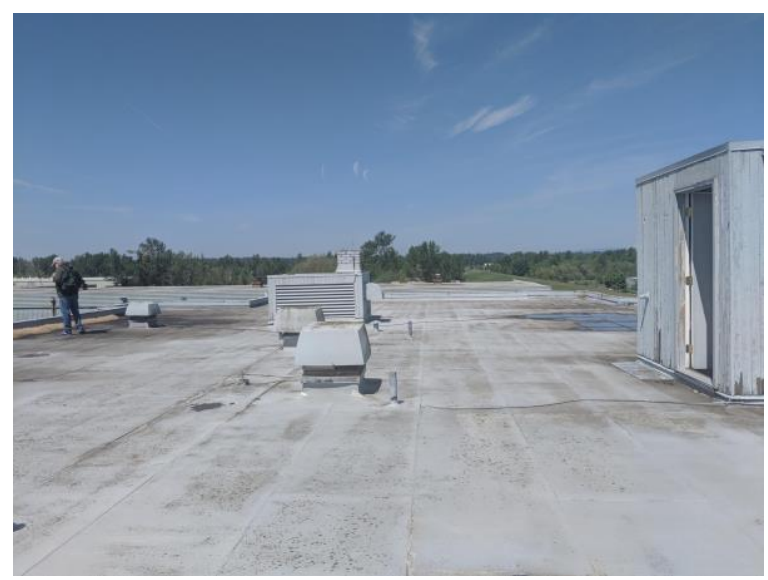

The roof of the building is generally in good shape, however there is some pooling, and some moss growth, which will likely result in repairs or drainage modifications. The roof is currently covered with asphalt rolls, which run at $\$ 39.97 /$ roll, at Lowes based on the damage on the roof, it seems that only the North corners will 
need replacing, estimated to be about 4 rolls, totaling $\$ 159.88 .{ }^{26}$ Due to the pooling it can be assumed that there are likely some support beams that would also need replacing, each 2”x12"x16' beam costing $\$ 20.95 .{ }^{27}$ The beams would need to span a 40’x20' space, which would require 38 boards costing $\$ 796.10$. Estimating the total material cost of roof repair to be $\$ 1752.08$ without consideration for labor. However, if it was found by an inspector that the entire roof surface needed replacement, estimates were also sought out. Quoted from Dr. Roof Inc. the material and labor would range from $\$ 3,750-\$ 15,000 .{ }^{28}$ Cascade United quoted the roofing cost at $\$ 28,000-\$ 38,000 .^{29}$

\section{Flooring}

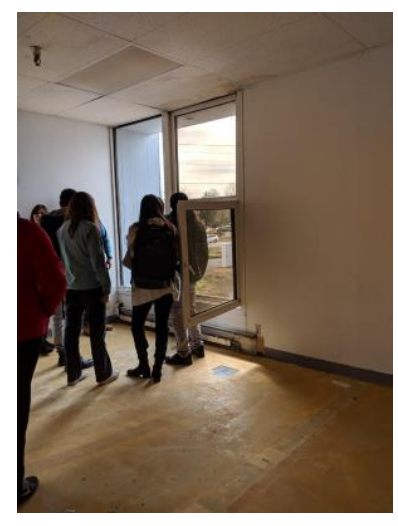

Each of the three floors of the office needs reflooring, the basement floors have unfinished tiling, and the upper floors have partial carpeting, where some of it has already been removed. Due to the proximity to the facilities, the regularity of people coming in with dirty work boots will likely happen more often than not, therefore, marmoleum flooring was chosen as a sustainable and hard-wearing

flooring option. The flooring has all been torn out by the current owner, so prep and installation are all that is needed. Depending on the state of the underlayment of the flooring the cost of installation will be different.

\footnotetext{
26 "Shasta White Roll Roofing." Lowes Home Improvement. Accessed February 15, 2019. https:/www.lowes.com/pd/Owens-Corning-3-ft-W-x-36-ft-L-100-sq-ft-Shasta-White-Roll-Roofing/3005563.

27 "Douglas Fir Lumber." Lowes Home Improvement. Accessed February 15, 2019. https:/www.lowes.com/pd/Top-Choice-2-x-12-x-16-ft-Douglas-Fir-Lumber-Common-1-562-in-x-11-5-in-x-16-ftActual/1000009796.

28 "Roof - Dr. Roof Inc." Telephone interview by author. February 15, 2019.

29 "Roof - Cascade United." Telephone interview by author. February 15, 2019.
} 
I received quotes from three flooring companies, Classique Floors, Floor Factors and Linoleum City.

Quoted by Classique Floors using sheets to prep the floors, each sheet being 3'x5', \$70 for labor and $\$ 45$ for material per sheet, totaling in $\$ 115$ per sheet. To cover all three floors it would take 748.8 sheets costing $\$ 86,112$. Cost of installation was quoted at $\$ 5.50 /$ yard for material and $\$ 24 /$ yard for labor, totaling in at $\$ 36,816$. A final quote of $\$ 122,928$ from Classique Floors. ${ }^{30}$

Quoted by Floor Factors using a skim coat for basic prep at $\$ .75 / \mathrm{sf}$ it would cost a total of $\$ 8,424$. They estimated marmoleum at $\$ 33.20$ /sy totaling $\$ 41,433.00$. Adhesive was quoted at $\$ 143 / 4$ gallon pail and required approximately 23 pails to cover all three floors, totaling \$3,289. Labor was quoted at 400 hours which would cost $\$ 36,000$. With material, adhesive, labor and prep, the total from Floor Factor is $\$ 89,146 .^{31}$

Quoted by Linoleum City, without details, totaling \$80,000. ${ }^{32}$

Siding

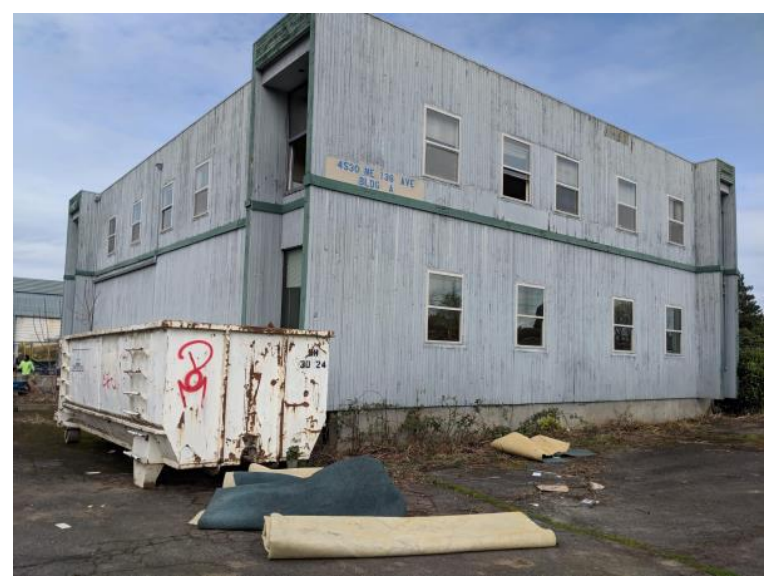

The current building has wooden siding, which has a life span of 20 years, however in renovating a longer lasting material would be chosen, so for the sake of the study, cost for fiber cement siding, which has a lifespan of $100+$ years, was found. The exterior of the building is

\footnotetext{
30 "Flooring - Classique Floors" Telephone interview by author. February 15, 2019.

31 "Flooring - Floor Factor." Telephone interview by author. February 15, 2019.

32 "Flooring - Linoleum City" Telephone interview by author. February 15, 2019.
} 
approximately 9,580 square feet. In order to remove the siding a local company, NW Commercial Exterior quoted it at 1.65/sf, which would total at $\$ 15,800 .{ }^{33}$ An online pricing found for the Portland area provided a range of $\$ 12,698-30,925$ for removal ${ }^{34}$. Based on the information provided by the contractor in Portland, the higher cost of removal may be due to dry rot repair if it were to be found when removing the original siding. Cost for labor and material for the fiber cement panels was estimated to be $\$ 10 /$ sf by KVN Construction $^{35}$, and $\$ 9.80 /$ sf $_{\text {by }}$ NW commercial exterior, meaning that cost for material and labor would be around \$85,262. And total cost to reside the building would be $\$ 101,062$. The online estimate gave a labor cost of $\$ 30,160$ and material cost of $\$ 54,643$, totaling $\$ 84,803$. Making the total for the online estimate approximately $\$ 106,615 .^{36}$

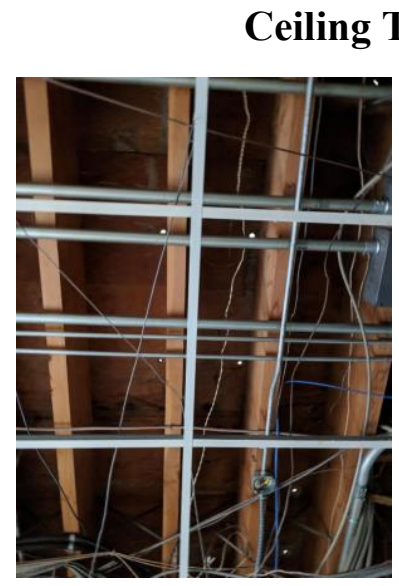

The entire building has gridding done for 2'X4' ceiling panels, however many of them are missing, or damaged. Because of this, new tiling estimates were found for the entire building, using an estimated square footage of 11,232 . If the panels were replaced with a comparable material, each panel would cost around $\$ .57$, totaling in $\$ 6,419$. If instead it was decided that a more sophisticated/esthetically pleasing panel would replace them, they would range at around $\$ 1.00 /$ sf totaling in about $\$ 11,232$ to retile the whole ceiling. ${ }^{37}$

\footnotetext{
33 "Siding - NW Commercial." Telephone interview by author. February 15, 2019.

34 "Cost to Install Fiber Cement Siding." Homewyse. Accessed February 15, 2019. https://www.homewyse.com/services/cost_to_install_fiber_cement_siding.html.

35 "Siding - KVN Construction." Telephone interview by author. February 15, 2019.

36 ibid

37 "Aristocrat Ceiling Panels." Ceilume. December 10, 2017. Accessed February 15, 2019. https://www.ceilume.com/panels/Aristocrat/White/.
} 


\section{Elevator}

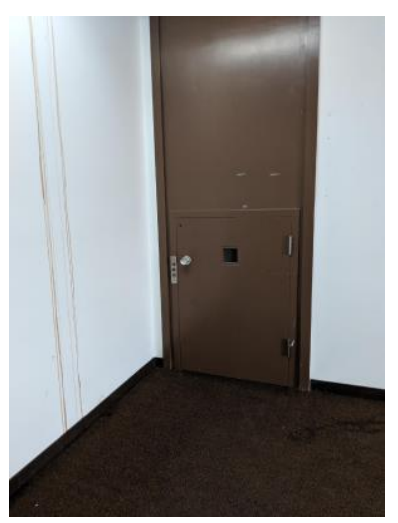

The current building already contains two means of egress, and bathrooms that meet code. However, the elevator needs to be updated from a service elevator to an elevator that can transport people, and a kitchenette needs to be updated in the basement to meet the needs of the user. Installing a new elevator was estimated at $\$ 20,000-\$ 28,000$ as a national average for a two to three story building by Reference. ${ }^{38}$

According to Fixr the cost for the elevator and installation ranges from $\$ 30,000-\$ 50,000$ depending on the location of the mechanical room, and number of stories. Due to the fact that the current mechanical room is separate, but close to the elevator, and that it is a three-story building, it is likely that the estimate for this building would be in the $\$ 40,000-\$ 50,000$ range. $^{39}$

\section{Insulation}

The insulation for the exterior of the building needs to be updated and would be done simultaneously with the exterior siding. Given an exterior of 9,580 sq ft an estimate for exterior insulation using batts was acquired totaling at $\$ 13,344.74$, without labor..$^{40}$ This includes the cost of 124 pink insulation batts, 300 sheets of $4 \times 8$ drywall, 6 boxes of drywalls screws, and 100 gallons of drywall joint compound. For interior wall insulation for bathrooms, conference rooms, and two private offices the cost of insulation and walls was estimated at $\$ 6,215.03$. This includes 52 batts of insulation, 143 sheets of drywall, 2 boxes of drywall screws, 48 gallons of drywall

\footnotetext{
38 "How Much Does a Commercial Elevator Cost?" Reference. 2019. Accessed February 20, 2019. https://www.reference.com/business-finance/much-commercial-elevator-cost-90a21afdb7cd32c4.

39 "Cost to Install an Elevator - Estimates and Prices at Fixr." Fixr. September 20, 2016. Accessed February 20, 2019. https://www.fixr.com/costs/elevator-installation.

40 "Calculator: Walls." Owens Corning Roofing and Insulation Products at The Home Depot. Accessed February 20, 2019. http://homedepot.owenscorning.com/insulation/helpful-resources/shopping-tools/insulationcalculator/project/325deacf-b085-4c3d-9932-d03a91bb564e/\#results.
} 
joint compound and 6 rolls of drywall tape.$^{41}$ Cost of labor generally is $30 \%$ of what the cost of material is and is therefore estimated at $\$ 3,911.95$. Making the total cost for installing the most vital walls and insulation $\$ 23,504.31$.

\begin{tabular}{|c|c|c|c|}
\hline Building System & $\begin{array}{l}\text { Business Quoted } \\
\text { From }\end{array}$ & Quote & Average/Total \\
\hline \multirow[t]{3}{*}{ Roof } & Dr. Roof Inc. & $\$ 3,750-\$ 15,000$ & \\
\hline & Cascade United & $\$ 28,000-\$ 38,000$ & $\$ 17,812.50$ \\
\hline & Lowes & 1,752.08 w/o Labor & \\
\hline \multirow[t]{3}{*}{$\begin{array}{l}\text { Flooring } \\
\text { Graphite Marmoleum }\end{array}$} & Classique Floors & $\begin{array}{l}\text { Prep Sheets (3’x5') } \\
\$ 70 / \text { sheet (labor) } \\
\text { \$45/sheet (material) } \\
\text { Marmoleum } \\
\text { \$5.50/yard (material) } \\
\text { \$24/yard (labor) } \\
\text { Total: \$122,928 } \\
\end{array}$ & \\
\hline & Linoleum City & $\$ 80,000$ & \\
\hline & Floor Factors & $\begin{array}{l}\text { \$33.20/sy (material) } \\
\$ 143 / \text { pail (adhesive) } \\
\$ 50 / \mathrm{h} \text { (labor) } \\
\$ .75 / \text { sf (prep) } \\
\text { Total: 89,146.00 }\end{array}$ & $\$ 97,358$ \\
\hline \multirow[t]{3}{*}{\begin{tabular}{|l|} 
Exterior Material \\
Fiber Cement Panels \\
\end{tabular}} & KVN Construction & $\begin{array}{l}\text { \$10/sf (material+labor) } \\
\text { Total: } \mathbf{9 5 , 8 0 0}\end{array}$ & \\
\hline & $\begin{array}{l}\text { NW Commercial } \\
\text { Exteriors }\end{array}$ & $\begin{array}{l}\$ 1.65 / \mathrm{sf} \text { (removal) } \\
\$ 9.80 / \mathrm{sf} \text { (material+labor) } \\
\text { Total: } \mathbf{\$ 1 0 9 , 6 9 1} \\
\quad \text { (minus removal) } \\
\quad \mathbf{\$ 9 3 , 8 8 4}\end{array}$ & \\
\hline & HomeWyse & \begin{tabular}{|l|}
$\$ 30,160$ (labor) \\
$\$ 54,643$ (material) \\
Total: $\mathbf{\$ 8 4 , 8 0 3}$ \\
\end{tabular} & $\$ 91,495.67$ \\
\hline \multirow[t]{2}{*}{ Ceiling Tiles } & Lowes & $\begin{array}{l}\$ .57 / \text { tile (standard } \\
\text { material) } \\
\text { Total: } \mathbf{6 , 4 1 9}\end{array}$ & \\
\hline & Celliume & $\begin{array}{l}\text { \$1.00/sf (higher quality) } \\
\text { Total: } \mathbf{\$ 1 1 , 2 3 2}\end{array}$ & $\$ 8,825.5$ \\
\hline \multirow{2}{*}{ Elevator } & Reference & $\$ 28,000-\$ 38,000$ & \\
\hline & Fixr & $\$ 40,000-\$ 50,000$ & $\$ 39,000$ \\
\hline
\end{tabular}

41 Ibid 


\begin{tabular}{|l|l|l|c|}
\hline & & $\begin{array}{l}\text { Exterior walls: } \\
\$ 13,344.74 \text { (material) }\end{array}$ & \\
& Owens Corning + & $\begin{array}{l}\$ 2,668.95 \text { (labor) } \\
\text { Interior walls: } \\
\$ 6,215.03 \text { (material) } \\
\end{array}$ & $\$ 23,471.73$ \\
\hline Home Depot & & & \\
\hline $\begin{array}{l}\text { Additional } \\
\text { unaccounted for costs }\end{array}$ & & $30 \%=83,380$ (labor) & $\$ 277,963.40$ \\
\hline
\end{tabular}

\section{Embodied Energy}

Using the concept model method outlined in the article Assessing the Energy Conservation Benefits of Historic Preservation embodied energy of the existing building will be determined as follows. This article uses Btu's or British Thermal Units to measure embodied energy. Btu's are traditional units of heat, which is the amount of energy required to raise the temperature of water by one degree Fahrenheit.

Initial embodied energy in materials used in the initial build - building type: Office

\begin{tabular}{|l|l|l|l|l|}
\hline $\begin{array}{l}\text { Embodied } \\
\text { Energy } \\
\text { Investment }\end{array}$ & $=$ & $\begin{array}{l}\text { Gross Floor Area of Existing } \\
\text { Building }\end{array}$ & $\mathbf{X}$ & $\begin{array}{l}\text { Invested Energy per } \\
\text { square foot specific to the } \\
\text { building type from Exhibit } \\
\mathbf{1}\end{array}$ \\
\hline & $=11,232 \mathrm{sq} . \mathrm{ft}$. & $\mathrm{X}$ & $1,640 \mathrm{MBtu} / \mathrm{sq} . \mathrm{ft}$. \\
\hline & $=18,420,480 \mathrm{MBtu}$ & \multicolumn{2}{|l}{} \\
\hline
\end{tabular}

Initial embodied energy in materials used in the initial build according to construction type: light (wood frame)

\begin{tabular}{|l|l|l|l|l|l|}
\hline $\begin{array}{l}\text { Embodied } \\
\text { Energy } \\
\text { Investment in } \\
\begin{array}{l}\text { Renovated } \\
\text { Buildings }\end{array}\end{array}$ & $=$ & $\begin{array}{l}\text { Gross } \\
\text { Floor Area } \\
\text { of Existing } \\
\text { Building }\end{array}$ & $\mathbf{X}$ & $\begin{array}{l}\text { Invested energy } \\
\text { per sq. ft. } \\
\text { specific to the } \\
\text { building type } \\
\text { from Exhibit 1 }\end{array}$ & $\mathbf{X}$
\end{tabular} \mid \begin{tabular}{l}
$\begin{array}{l}\text { Fraction of materials and } \\
\text { construction of the existing } \\
\text { historic building that is } \\
\text { being replaced or added in } \\
\text { the renovation process. }\end{array}$ \\
\hline
\end{tabular}




\begin{tabular}{|l|l|l|l|l|l|l|}
\hline & $=$ & $\begin{array}{l}11,232 \\
\text { ft. sq. }\end{array}$ & X & 3,100 Btu/sq. ft. & X & $2 / 3$ \\
\hline & $=$ & $23,189,587.20$ & Btu \\
\hline
\end{tabular}

Initial building embodied energy total: 20,739,438 MBtu's

\begin{tabular}{|c|c|c|c|c|c|c|}
\hline $\begin{array}{l}\text { Annual } \\
\text { Operational } \\
\text { Energy in } \\
\text { Renovated } \\
\text { Buildings } \\
\text { (recurring) }\end{array}$ & $=$ & $\begin{array}{l}\text { Gross } \\
\text { Floor Area } \\
\text { of Existing } \\
\text { Building }\end{array}$ & $\mathbf{X}$ & $\begin{array}{l}\text { Energy } \\
\text { consumption in } \\
\text { buildings of } \\
\text { similar type in } \\
\text { the same } \\
\text { climatic region, } \\
1975 \text { levels, } \\
\text { Exhibit } 3 \\
\end{array}$ & $\mathbf{X}$ & $\begin{array}{l}\text { Multiplier representing the } \\
\text { extent to which renovations } \\
\text { may be expected to make } \\
\text { the existing building energy } \\
\text { consumption equivalent to } \\
\text { new buildings. }\end{array}$ \\
\hline & $=$ & $\begin{array}{l}11,232 \text { sq. } \\
\mathrm{ft.}\end{array}$ & $X$ & $65 \mathrm{MBtu} / \mathrm{sq} . \mathrm{ft}$. & $X$ & 1.25 \\
\hline
\end{tabular}

Total Embodied energy initial and renovated for one year: 21,652,038 MBtu. After forty years it would be 57,243,438 MBtu's.

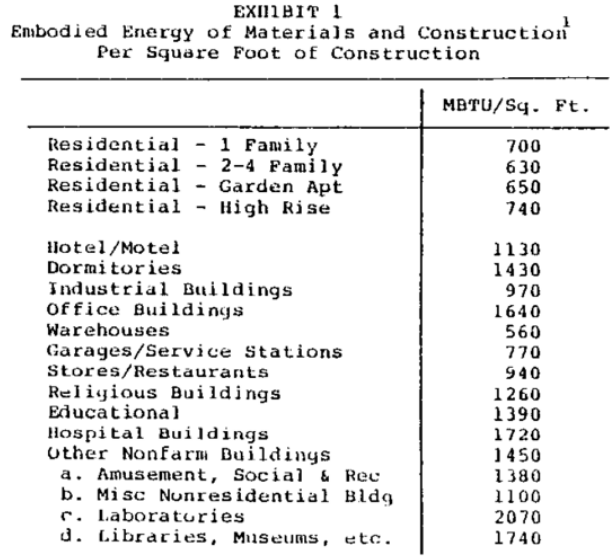

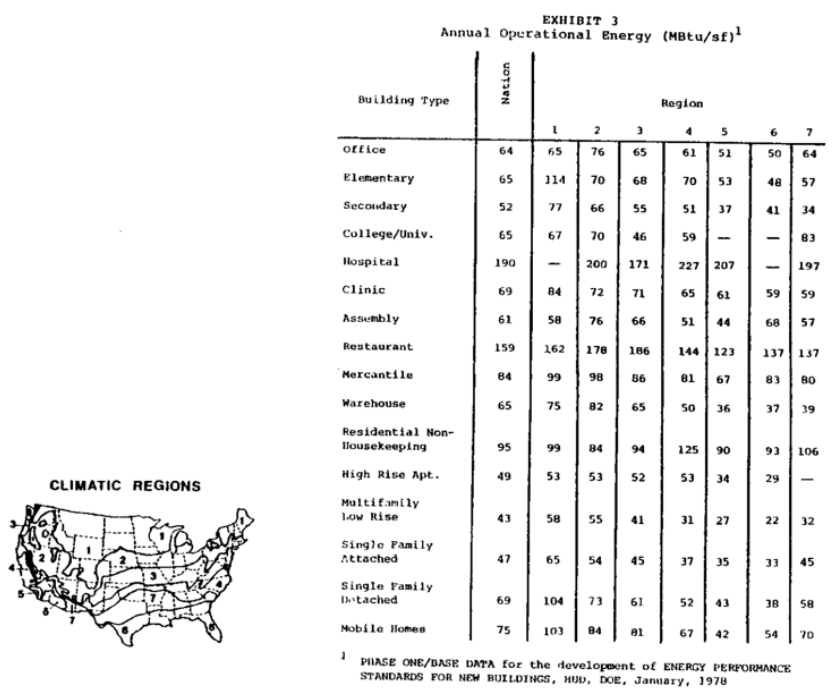

\section{New Construction}

\section{Cost}

The cost to build new, according to Jones Lang LaSalle (JLL) based on a national average, the cost to build an office of the same size would be over $\$ 2,200,000$, at $\$ 196.49 / \mathrm{sq}$. ft. ${ }^{42}$ In a journal entry focused on cost of construction per sq. ft. Portland was found to range from

\footnotetext{
${ }^{42}$ Burns, Todd. "The True Cost of Building Your Office Is Not as High as You Think." JLL. Accessed February 20, 2019. https://www.officerenew.com/tips-and-trends/process/average-office-fit-out-costs/.
} 
$\$ 165-\$ 220$, averaging at $\$ 192.50 /$ sq. ft. totaling $\$ 2,162,160$ for an office of the same size as the one in this study. ${ }^{43}$

\section{Embodied Energy}

Using the same article as with the renovated building the embodied energy of a newly constructed building was determined as follows.

\begin{tabular}{|c|c|c|c|c|}
\hline \multirow[t]{2}{*}{$\begin{array}{l}\text { Demolition } \\
\text { Energy for } \\
\text { Existing } \\
\text { Buildings }\end{array}$} & $=$ & $\begin{array}{l}\text { Gross Floor Area of Existing } \\
\text { Building }\end{array}$ & $\mathbf{X}$ & $\begin{array}{l}\text { Demolition energy of } \\
\text { materials per sq. ft. of } \\
\text { construction for buildings } \\
\text { of similar size and } \\
\text { construction type, Exhibit } \\
2\end{array}$ \\
\hline & $=$ & 11,232 sq. ft. & $\mathrm{X}$ & $3,100 \mathrm{Btu} / \mathrm{sq} . \mathrm{ft}$. \\
\hline & $=$ & & & $34,819,200 \mathrm{Btu}$ \\
\hline \multirow[t]{3}{*}{$\begin{array}{l}\text { Embodied } \\
\text { Energy } \\
\text { Investment }\end{array}$} & $=$ & $\begin{array}{l}\text { Gross Floor Area of New } \\
\text { Building }\end{array}$ & $\mathbf{X}$ & $\begin{array}{l}\text { Invested Energy per } \\
\text { square foot specific to the } \\
\text { building type from Exhibit } \\
1\end{array}$ \\
\hline & $=$ & 11,232 sq. ft. & $X$ & $1,640 \mathrm{MBtu} / \mathrm{sq}$. ft. \\
\hline & $=$ & & & $18,420,480 \mathrm{MBt}$ \\
\hline \multirow[t]{3}{*}{$\begin{array}{l}\text { Annual } \\
\text { Operational } \\
\text { Energy in New } \\
\text { Buildings } \\
\text { (recurring) } \\
\end{array}$} & $=$ & $\begin{array}{l}\text { Gross Floor Area of New } \\
\text { Building }\end{array}$ & $\mathbf{X}$ & $\begin{array}{l}\text { Energy consumption in } \\
\text { buildings of similar type in } \\
\text { the same climatic region, } \\
1975 \text { levels Exhibit } 3\end{array}$ \\
\hline & $=$ & 11,232 sq. ft. & $\mathrm{X}$ & $65 \mathrm{Mbtu} / \mathrm{sq} . \mathrm{ft}$. \\
\hline & $=$ & & & $730,080 \mathrm{Mbtt}$ \\
\hline
\end{tabular}

This means that the total embodied energy for the new building would start at 21,902,400 MBtu, and after one year would be up to 22,632,480 MBtu. After forty years the buildings Btus would be 51,105,600 MBtu's.

\footnotetext{
${ }^{43}$ Culverwell, Wendy. "What It Costs to Build a Portland Office Building." Portland Business Journal. February 25, 2014. Accessed February 20, 2019. https://www.bizjournals.com/portland/blog/real-estate-daily/2014/02/rlb-whatit-costs-to-build-an-office.html.
} 


\section{Comparison}

Within this study, it was found that modest renovations for the COR, three-story office building, built fifty years ago would cost approximately $\$ 361,400$. The cost for a new building of the same size as the old was found to be approximately $\$ 950,000$ to $\$ 2,200,000$. Considering the fact that the cost of new construction would be three to five times as much as the cost of renovation as outlined in this study, the economic benefit of renovation is clear in the case of the COR Building.

The other method of analysis that can be used for comparison is the embodied energy within each building, old and new. The existing building has an embodied energy that has already been invested of $18,420,480 \mathrm{MBtu}$, the renovation investment is $23,189.58 \mathrm{MBtu}$ 's, and the operational energy per year is $912,600 \mathrm{MBtu}$. This means that the total invested embodied energy in this renovation after one year would be 21,652,038 MBtu. Whereas the embodied energy of the new construction takes into consideration the embodied energy that is already present within the existing building, and in the demolition of it, which is 34,819.20 MBtu. The embodied energy investment for a new construction of the same size would be $18,420,480 \mathrm{MBtu}$ and the operational embodied energy is $730,080 \mathrm{MBtu}$. The total embodied energy of the new building after one year would be $22,632,480 \mathrm{MBtu}$. In only one year of operation the new building would already have an embodied energy greater than the renovated alternative by over one million MBtu's. considering that, and the fact that the materials and embodied energy in the initial building will have gone to waste, a strong argument can be made for the renovation of the architecture that is already present.

In the years that come after the initial renovation or construction of a building is when the embodied energy begins to show how long it really takes for a new building to outweigh it's 
initial construction costs. After forty years, the renovated COR building would have a total of 57,243,438 MBtu's and a new COR building would have 51,105,600 MBtu's. While this shows that by the time that the materials in the original/renovated building would be at or nearing the end of their lifespan, the renovated would be higher than that of the new building. It also shows that the building would still have a lot of time left in it that would be wasted on a new building. These numbers are also based on assumptions that I made, based on a modest renovation. Given a better renovation the energy to run the renovated building could be helped with newer technologies or insulation that I don't know how to calculate for, therefore the time that it takes for the new to outweigh the renovated could be much less, or much more.

\section{Conclusion}

This thesis highlights a number of reasons why architects should embrace sustainability through renovation, and how renovation benefits the environment and the economy. Buildings are often valued based on their historic and cultural attributes alone. As the world turns its focus towards sustainability, the construction industry, being one of the greatest contributors to climate change worldwide and the architecture community which drives building design, should lead the way in reducing waste through renovation and sustainable design methods. Studies such as the MVAT and MODM consider the historic and cultural attributes of an existing building being evaluated for renovation and tend to lack focus on the structure and materiality and embodied energy that the building itself holds. New methods for examining buildings such as Life Cycle Assessment and embodied energy take into consideration more of the environmental and material value of the existing building. Taking the environmental and material value into consideration allows for a focus on the building and its inherent value instead of the contextual value. Using the MVAT, the value of the building seemed limited, however within the MODM 
study, the value of the building itself is seen before it was weighed against the contextual values. Without the contextual values, the building had a value of .7, but was brought down to .35 when brought into consideration with the context.

As is noted in the comparison section of this paper, the economic and embodied energy values both show the benefit of renovation over building new. Not only does it take less money, and less embodied energy to renovate this building, but it also allows for other design methods, and environmental influences to come into play. By choosing renovation over demolition, an architect is faced with challenges that they wouldn't ordinarily be faced with, and because of that, the designs are often much more interesting. But, even within this simple renovation, the lower cost would allow for larger sustainability decisions to be made. These decisions include the possible inclusion of a green roof, solar panels, more sustainable choices for heating/cooling and electricity. Renovation is only one of the ways in which architects can lead in sustainable practices.

Merlino's book catalogues many existing buildings that have been renovated over the years, and the ways in which the architects were able to further incorporate sustainability practices beyond the act of renovation. These practices include; individual temperature controls, daylighting practices for passive heating/cooling, recycled materials (perfect for renovation projects, to further that statement), low-flow plumbing, and LED lighting among many others. Merlino's book also catalogues the renovation costs of the buildings that she notes, which are significantly higher than the estimated cost that was found for the modest COR renovation. The disparity in the cost of renovation for the COR building and that of the ones in Merino's book could be due to the complexity of renovation, as well as the building type. Many buildings in Portland are demolished or deconstructed due to the complexity of their masonry building 
materials. In a masonry building it is more complex to bring a building up to seismic codes, as well as to repair than their lightweight wood frame counterpart. Therefore, there are likely many instances where the renovation cost may climb up to a more comparable number to that of building new. Because this is often the case in historic buildings, especially in Portland, more methods for encouraging renovation may need to be put into place in order to get more architects and contractors on board.

In a study done in China and New Zealand, a correlation between embodied energy and construction costs were established. Knowing that there is a correlation, it may become possible for legislation to be passed for fees that take into account embodied energy. If there were stronger economic consequences to the things that negatively impact the environment, such as large amounts of embodied energy and material waste, the benefits of renovation may become clearer, and more widely accepted as a viable option within the building industry.

This thesis is only the beginning of a study of the influence that renovation can have on architecture, and the ways in which it can influence the industry. If renovation becomes a more recognized and implemented practice, codes and expectations for architects and contractors can also begin to change. If we take into consideration the environmental impact of our buildings, and begin to place limits on the demolition industry, the way in which architecture impacts the environment can drastically change in direction to a more sustainable and positive influence. Embracing renovation doesn't have to mean that we stop progressing as a profession, but instead that we are being challenged in new ways, and being more respectful of the materials and the environment that allow us to create and design. 


\section{Bibliography}

"About." City of Roses Disposal. Accessed February 20, 2019. https:/cityofrosesdisposal.com/.

"Aristocrat Ceiling Panels." Ceilume. December 10, 2017. Accessed February 15, 2019. https://www.ceilume.com/panels/Aristocrat/White/.

"Calculator: Walls." Owens Corning Roofing and Insulation Products at The Home Depot. Accessed February 20, 2019. http://homedepot.owenscorning.com/insulation/helpfulresources/shopping-tools/insulation-calculator/project/325deacf-b085-4c3d-9932d03a91bb564e/\#results.

"Chapter 17.106 Deconstruction of Buildings Law." Drugs and Vice Division RSS. Accessed

December 06, 2018. https://www.portlandoregon.gov/citycode/71899.

"Code Analysis." E-mail to Jeshua De Jongh. February 18, 2019.

"Cost to Install an Elevator - Estimates and Prices at Fixr." Fixr. September 20, 2016. Accessed February 20, 2019. https://www.fixr.com/costs/elevator-installation.

"Cost to Install Fiber Cement Siding." Homewyse. Accessed February 15, 2019. https://www.homewyse.com/services/cost_to_install_fiber_cement_siding.html.

"Douglas Fir Lumber." Lowes Home Improvement. Accessed February 15, 2019. https://www.lowes.com/pd/Top-Choice-2-x-12-x-16-ft-Douglas-Fir-Lumber-Common-1562-in-x-11-5-in-x-16-ft-Actual/1000009796.

"Historic Resource Protections." Historic Resources and Preservation RSS. May 04, 2017. Accessed October 30, 2018. https://www.portlandoregon.gov/bps/article/133692.

"How Much Does a Commercial Elevator Cost?" Reference. 2019. Accessed February 20, 2019. https://www.reference.com/business-finance/much-commercial-elevator-cost$90 \mathrm{a} 21 \mathrm{afdb} 7 \mathrm{~cd} 32 \mathrm{c} 4$. 
"Portland State University - Lincoln Hall Renovation." Bora. Accessed October 30, 2018. https://bora.co/project/lincoln-hall-renovation/.

"PortlandMaps." PortlandMaps. Accessed February 20, 2019. https://www.portlandmaps.com/.

"Shasta White Roll Roofing." Lowes Home Improvement. Accessed February 15, 2019. https://www.lowes.com/pd/Owens-Corning-3-ft-W-x-36-ft-L-100-sq-ft-Shasta-WhiteRoll-Roofing/3005563.

Berg, Fredrik, and Mie Fuglseth. "Life Cycle Assessment and Historic Buildings: Energyefficiency Refurbishment versus New Construction in Norway." Journal of Architectural Conservation24, no. 2 (July 18, 2018): 152-67. Accessed October 28, 2018. doi:10.1080/13556207.2018.1493664.

Burns, Todd. "The True Cost of Building Your Office Is Not as High as You Think." JLL. Accessed February 20, 2019. https://www.officerenew.com/tips-andtrends/process/average-office-fit-out-costs/.

Culverwell, Wendy. "What It Costs to Build a Portland Office Building." Portland Business Journal. February 25, 2014. Accessed February 20, 2019. https://www.bizjournals.com/portland/blog/real-estate-daily/2014/02/rlb-what-it-costs-tobuild-an-office.html.

Faludi, Jeremy, Michael D. Lepech, and George Loisos. "USING LIFE CYCLE ASSESSMENT METHODS TO GUIDE ARCHITECTURAL DECISION-MAKING FOR SUSTAINABLE PREFABRICATED MODULAR BUILDINGS." Journal of Green Building7, no. 3 (2012): 151-70. Accessed October 25, 2018. doi:10.3992/jgb.7.3.151. Ferretti, Valentina, Marta Bottero, and Giulio Mondini. "Decision Making and Cultural Heritage: An Application of the Multi-Attribute Value Theory for the Reuse of Historical 
Buildings." Journal of Cultural Heritage15, no. 6 (November/December 2014): 644-55. Accessed October 25, 2018. doi:10.1016/j.culher.2013.12.007.

Icc. "CHAPTER 10 MEANS OF EGRESS ." CHAPTER 11 [RE] ENERGY EFFICIENCY | 2012 International Residential Code | ICC PublicACCESS. August 2017. Accessed February 25, 2019. https://codes.iccsafe.org/content/IBC2018/chapter-10-means-ofegress.

International Code Council. "CHAPTER 3O CCUPANCY CLASSIFICATION AND USE ." CHAPTER 11 [RE] ENERGY EFFICIENCY | 2012 International Residential Code | ICC PublicACCESS. Accessed February 25, 2019. https://codes.iccsafe.org/content/IBC2018/chapter-3-occupancy-classification-and-use.

Kayas, Ece. "Life Cycle Cost Awareness Among Architects: The Case of Turkey." Master's thesis, Izmir Institute of Technology, 2009.

Merlino, Kathryn Rogers. Building Reuse: Sustainability, Preservation, and the Value of Design. Seattle: University of Washington Press, 2018.

Stavreva, Brigita. "New vs. Old: New Architecture of Purpose in Old Settings." Master's thesis, Virginia Polytechnic Institute and State University, 2017.

Wang, Huey-Jiun, and Zhi-Teng Zeng. "A Multi-objective Decision-making Process for Reuse Selection of Historic Buildings." Expert Systems with Applications37, no. 2 (2010): 1241-249. Accessed October 28, 2018. doi:10.1016/j.eswa.2009.06.034. 